\title{
In moderate communicating hydrocephalus of human fetuses, ependymal denudation is a common feature that may result in abnormal neurogenesis
}

\author{
María Dolores Domínguez¹, Antonio J Jiménez*1, Patricia Páez¹, \\ Bernardo Weil ${ }^{2}$, Miguel Angel Arráez ${ }^{3}$, Esteban M Rodríguez ${ }^{4}$ and José- \\ Manuel Pérez-Fígares ${ }^{1}$
}

Address: ${ }^{1}$ Departamento de Biología Celular, Genética y Fisiología. Universidad de Málaga. E-29071 Málaga, Spain, ${ }^{2}$ Servicio de Anatomía Patológica Hospital Carlos Haya, Málaga. Spain, ${ }^{3}$ Servicio de Neurocirugía Hospital Carlos Haya, Málaga. Spain and ${ }^{4}$ Instituto de Histología y Patología, Universidad Austral de Chile, Valdivia, Chile

Email: Antonio J Jiménez* - ajjimenez@uma.es

* Corresponding author

from 49th Annual Meeting of the Society for Research into Hydrocephalus and Spina Bifida Barcelona, Spain, 29 June - 2 July 2005

Published: 30 December 2005

Cerebrospinal Fluid Research 2005, 2(Suppl I):S5 doi:I0.II86/I743-8454-2-SI-S5

\section{Background}

Recent investigations carried out in natural and experimental mutant mice have provided strong evidence that a primary alteration of the ependymal cell lineage triggers a moderate foetal hydrocephalus $[1,2]$. In human cases of hydrocephalus, however, ependymal loss has been regarded as resulting from the ventricular dilatation due to the accumulation of cerebrospinal fluid [3].

\section{Materials and methods}

The present investigation was carried out in 16-40 week old human foetuses with a communicating hydrocephalus and displaying a moderate dilatation of the ventricular cavities $(n=8)$, and foetuses of similar ages with no neuropathological alterations $(n=15)$. Paraffin sections throughout the walls of the cerebral aqueduct and lateral ventricles were processed for lectin binding and immunocytochemistry using ependyma, astroglia, neuroblasts and macrophague markers.

\section{Results}

Large areas of ependymal denudation were found in the aqueduct and lateral ventricles of all foetuses developing a communicating hydrocephalus. At variance, no ependymal detachment was observed in non-hydrocephalic foetuses. In the youngest foetuses with hydrocephalus, denuded areas were not covered by astrocytes or other organized cell elements, leaving the neuropile directly exposed to the ventricular lumen. The area devoid of ependyma increased as the foetus developed. In the oldest foetuses studied, the denuded areas of the lateral ventricles were lined by a dense plexus of astrocytes. Under the denuded surface the presence of ependymal rosettes was observed. In the denuded areas of the lateral ventricles of hydrocephalic foetuses it was found (i) a loss of the germinal ependymal zone, (ii) disorganization of the subventricular zone and, (iii) abnormal migration of neuroblasts into the ventricular cavity.

\section{Conclusion}

The early loss of ependyma in human hydrocephalic foetuses would be associated to both, the hydrocephalic process and an abnormal migration of neuroblasts.

\section{Acknowledgements}

Supported by grants from FIS, PI 030756 and Red CIEN C/0306, Instituto de Salud Carlos III, and Servicio Andaluz de Salud, Spain to JMP-F; and Fondecyt 1030256, Chile to EMR.

\section{References}

I. Jiménez AJ, Tomé M, Páez P, Wagner C, Rodríguez S, Fernández-Llebrez $\mathrm{P}$, Rodríguez EM, Pérez-Fígares JM: A programmed ependymal denudation occurring during the embryonic life precedes development of congenital hydrocephalus in the mutant mouse hyh. I Neuropathol Exp Neurol 200 I, 60: I I05-I I I 9.

2. Davy BE, Robinson ML: Congenital hydrocephalus in hy3 mice is caused by a frameshift mutation in Hydin, a large novel gene. Hum Mol Genet 2003, I 2: I I63-I I70. 
3. Sarnat HB: Ependymal reactions to injury. A review. J Neuropathol Exp Neurol 1995, 54: I-I5.

Publish with Bio Med Central and every scientist can read your work free of charge

"BioMed Central will be the most significant development for disseminating the results of biomedical research in our lifetime. " Sir Paul Nurse, Cancer Research UK

Your research papers will be:

- available free of charge to the entire biomedical community

- peer reviewed and published immediately upon acceptance

- cited in PubMed and archived on PubMed Central

- yours - you keep the copyright

Submit your manuscript here:

http://www.biomedcentral.com/info/publishing_adv.asp 